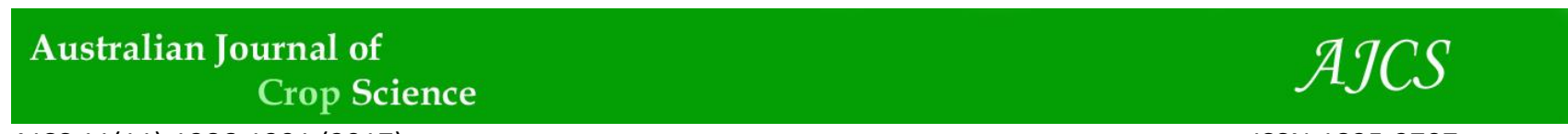

AJCS 11(11):1386-1391 (2017)

ISSN:1835-2707

doi: 10.21475/ajcs.17.11.11.pne439

\title{
Expansion of palm oil (Elaeis guineensis Jacq.) in the state of Maranhão and soil water deficit limitations in the Brazilian Amazon
}

\section{Lucieta Guerreiro Martorano $^{1 *}$, José Reinaldo da Silva Cabral de Moraes ${ }^{2}$, Leila Sheila Silva Lisboa ${ }^{3}$, Rui Alberto Gomes Junior ${ }^{1}$, Victor Proença do Amaral ${ }^{4}$, Lucas Eduardo de Oliveira Aparecido ${ }^{2}$}

\author{
${ }^{1}$ Embrapa Eastern Amazon, Belém, Pará, Brazil \\ ${ }^{2}$ São Paulo State University (Unesp), School of Agricultural and Veterinarian Sciences, Jaboticabal, Department \\ of Exact Sciences, Brazil \\ ${ }^{3}$ ESALQ/CENA, Piracicaba, São Paulo, Brazil \\ ${ }^{4}$ Federal Rural University of the Amazon, Belém, PA, Brazil
}

*Corresponding author: lucieta.martorano@embrapa.br

\begin{abstract}
Oil palm is considered the crop with the highest oil production per planted area unit. This condition has driven the Brazilian government to create the Sustainable Oil Palm Production Program. Since 2009, the agroenergy production chain has used oil palm as a viable and profitable crop to recover deforested areas in the Amazon. The aim of this study was to assess hydric conditions able to indicate the potential to expand oil palm crops in the state of Maranhão, even in the Legal Amazon. The climate database used (average and extreme temperature in degrees Celsius; rainfall values; relative humidity, and vapour-pressure deficit). Water deficit values were was obtained by comparing the potential evapotranspiration of oil palm (ETc) to actual rainfall (ER). Water balance was calculated based on available water capacity of $125 \mathrm{~mm}$. month ${ }^{-1}$. Evapotranspiration was obtained using the methodology according to the climate database available to calculate the evapotranspiration rate in an area planted with oil palm in this study. The water deficit values show no restriction in the soil water replacement between January and June. However, from July to December, the water deficit varies between 200 and $300 \mathrm{~mm}$. The levels showed that, in the areas evaluated, oil palm crops will require irrigation. In this period, yield was estimated at 17 tons ha ${ }^{-1}$ when the water deficit was considered at $210 \mathrm{~mm}$ and 14 tons ha ${ }^{-1}$ for a deficit of 380 $\mathrm{mm}$. This result reinforces that oil palm production may drop by more than $50 \%$ due to water deficits and the crop will greatly impact the economy and the environment if the irrigation strategy is adopted in the areas of Maranhão.
\end{abstract}

Keywords: Rainfall, environmental damage, evapotranspiration, dry season, yield.

\section{Introduction}

In Brazil, the Sustainable Oil Palm Production Program has driven agroenergy production, which fostered the expansion of crops in the Brazilian Amazon (Homma and Vieira, 2012). The Legal Amazon in Brazil comprehends nine states, but it is important to point out that part of this region of around 4 million $\mathrm{km}^{2}$ has vegetation patterns typical of the Amazon biome, which covers six states (Acre, Amapá, Amazonas, Pará, Rondônia, and Roraima), while other areas have typical vegetation of the Cerrado/Amazon ecotone belonging to the states of Maranhão, Mato Grosso, and Tocantins. Oil palm (Elaeis guineensis Jacq.) stands out among oleaginous plants as the crop with the highest oil production per planted area (Sheil et al., 2009) and has become an alternative in public policies that use biofuels in the energy matrix (Kaewmai et al., 2012). It is a species typical of tropical climates originated in Tropical Africa with type- $\mathrm{C}_{3}$ photosynthesis pathway and indicated for growth between $16^{\circ} \mathrm{N}$ and $15^{\circ} \mathrm{S}$. Oil palm's productivity per planted area unit is high and the species is grown in 43 countries for a total of 16.4 million hectares worldwide (Food and Agriculture Organization of the United Nations, 2014). Oil palm has entered the biodiesel chain and has become an alternative source of income, besides being included in the productive process in the Brazilian state of Pará in the recovery of degraded land in the
Amazon (Villela et al., 2014). In Pará, in agricultural areas considered preferential by zoning (Ramalho Filho and Mota, 2010), the crop has been expanding and creating agricultural and industrial jobs. Hence, despite being a poor habitat for biodiversity in the Amazon (Lees et al., 2015), oil palm crops may be an important alternative for regional development given its positive role in the potential recovery of degraded areas, income generation, and renewable energy production (Koh and Ghazoul, 2008; Corley, 2009). The Sustainable Oil Palm Production Program in Brazil has driven agroenergy production in the Amazon aiming to expand its planted area and the supply of tools to ensure environmentally and socially sustainable production. Much of the area targeted by the program lies in the northern portion of the Eastern Amazon due to its edaphoclimatic aptitude. The concern was to increase Brazil's competitiveness in palm oil production since the national production was inexpressive compared to countries such as Malaysia and Indonesia despite the 70 million hectares of area with great potential for growing those palm trees, including deforested land on its way to becoming degraded areas in the Amazon (Nogueira, 2011). However, according to Martorano et al. (2011), those areas must have eco-agroclimatic potential, particularly regarding high soil water content since extended water stress directly 
impacts the growth and yield of those plants (Brodribb, 2009). The effect of water stress on oil palm production varies according to the season, severity, and plant phenological and development phases (Carr, 2011). In countries such as Malaysia, with small seasonal changes, yields are relatively uniform with annual losses of 12 to $15 \%$. In contrast, in regions with well-defined dry seasons such as Benin, losses can amount to 35 to $40 \%$ (Nouy et al., 1999; Corley and Tinker, 2003). However, development in the northern region of the Eastern Amazon has been inhibited by environmental issues, besides the high costs of logistics to provide inputs, which led farmers to consider the possibility of expanding the crop to other areas or regions in the country (Teles et al., 2016). This way, this study aimed to assess agroclimatic conditions, particularly regarding water supply, capable of indicating characteristics that allow oil palm to expand to the northeastern portion of the state of Maranhão, which lies in the Brazilian Amazon.

\section{Results and Discussion}

In the state of Maranhão, an area that belongs to the Legal Amazon, the prevailing climate type is $\mathrm{Am}_{4}$ to $\mathrm{Aw}_{5}$, which is characterized by months with rainfall below $60 \mathrm{~mm}$ and annual rainfall between 1,500 and 2,000 $\mathrm{mm}$. In the state of Pará, the main oil palm producer in Brazil, production centers are concentrated in areas with $\mathrm{Af}_{1}$ to $\mathrm{Af}_{3}$ climate, which means the driest months have rainfall above $60 \mathrm{~mm}$ and annual rainfall is between 2,500 and 3,000 mm (Fig 1). That highlights the fact that climate conditions in northeastern Maranhão feature extended dry periods. An analysis of the thermal ranges presented in Fig 2 (A, B, and C) shows that, in the territory of the state of Maranhão that belongs to the Brazilian Amazon, maximum annual temperatures range from 31.0 to $32.3{ }^{\circ} \mathrm{C}$ (Fig 2A). In terms of minimum temperature, the mean values are between 19.5 and $22.3{ }^{\circ} \mathrm{C}$ (Fig 2B), with the lowest values occurring in the southern portion of the study area. The mean temperatures ranged from 25.5 to $27.0^{\circ} \mathrm{C}$ (Fig 2C). According to Ramalho Filho et al. (2010), the temperature range recommended for the full development of the crop studied is between 22 and $30{ }^{\circ} \mathrm{C}$ and thermal stress effects are felt when mean air temperature drops below $18{ }^{\circ} \mathrm{C}$. According to Corley and Tinker (2003), temperature has an inhibitory effect on photosynthesis when it reaches between 33 and $40{ }^{\circ} \mathrm{C}$, mainly because of the induced saturation deficit, which causes stomata to close. It is observed that air temperature in the area studied does not limit crops since the thermal ranges favor oil palm. Relative humidity in the area of interest ranges from 77 to $80 \%$ (Fig 3) and the vapor pressure deficit (VPD) is between 0.72 and $0.86 \mathrm{kPa}$ (Fig 4). Nkodo et al. (2016), in a study on oil palm by the coast of Cameroon, observed that mean relative humidity of $85 \% 12$ months and 24 months prior to harvest had the greatest impact on production with respect to the number of bunches and weight of the fruits. However, VPD is closely related to transpiration rates in tropical forests (Marenco et al., 2014). Dufrêne and Saugier (1993), in a study in the Ivory Coast, confirmed the sensitivity of stomatal conductance to changes in VPD and reported an exponential decline over a range of 0.8 to $2.0 \mathrm{kPa}$. Nelson et al. (2006) observed mean variations by $1.1 \mathrm{kPa}$ in VPD, reaching $1.8 \mathrm{kPa}$ during the day, in evaluations carried out at different sites in Papua New Guinea. When the spatial distribution of rainfall is analyzed, annual rainfall levels of 1,600 to $2,000 \mathrm{~mm}$ (Fig 5) can be observed. In this context, Ramalho Filho et al. (2010) point out that annual rainfall should be above $2,000 \mathrm{~mm}$, which shows the levels in the study area are below those considered acceptable for the plant. In Kedah, Malaysia, Henson and Harun (2007) found that actual evapotranspiration (ET) rates in plants between seven and eight years old during different drought periods ranged between 3.9 and $2.7 \mathrm{~mm} \mathrm{~d}^{-1}$ and the corresponding ET/ETo (potential evapotranspiration) ratios ranged from 0.85 to 0.50 , i.e., the crop's water requirements cannot exceed $50 \%$ of the water available in the soil. Nelson et al. (2006), in studies carried out at two different sites in Papua New Guinea with annual rainfall between $3,614 \mathrm{~mm}$ and $2,415 \mathrm{~mm}$, reported ET for the crop of $3.2 \mathrm{~mm} \mathrm{~d}^{-1}$ and 4.1 $\mathrm{mm} \mathrm{d}^{-1}$, respectively. Since 1 ha can host 143 oil palms, minimally meeting this water demand of $2.7 \mathrm{~mm} \mathrm{~d}^{-1}$ would require $27 \mathrm{~m}^{3}$ with a water demand per plant of $188 . \mathrm{L} \mathrm{d}^{-1}$.

Nonetheless, in order to prevent or reduce the effects of water stress on oil palm, the yields of irrigation systems in areas that do not meet the plant's water demand, as observed by Teles et al. (2016) in field experiments in the Brazilian cerrado biome, are similar to that of crop areas with satisfactory water supply with no irrigation in several regions worldwide that produce palm oil. Another noteworthy aspect is the activities related to biodiesel production of mills and palm oil industrialization plants, whose processes require large amounts of potable water. The considerations by Suttayakul et al. (2016) highlight the need of production centers to establish a water management plan for the palm oil industry in order to subsidize the production of food and alternative energy for the biofuel market, comprehending the direct and indirect use of water. In this context, adopting the water replacement strategy in that area of Maranhão to incentive oil palm crops requires not only accounting for the water to maintain the agricultural system productive but, above all, also the water supply to the factories processing the product. An analysis of water deficit values per semester shows that, between January and June, soil water replacement will not be required since the values are below those found for soil water capacity of $125 \mathrm{~mm}$ (Fig 6A). However, the crops will require irrigation from July to December since the water deficit is greater than $300 \mathrm{~mm}$ (Fig 6B). When the range of 563 to $712 \mathrm{~mm}$ of total annual water deficit in the area assessed was considered, the potential production estimated by the equation used by Corley and Tinker (2003) was between 10 and 7 tons ha ${ }^{-1}$, which show that, under those conditions, annual water deficits reduce the genetic production potential. However, when the period of greatest water deficit, i.e., between July and December, is analyzed, the values can reach from 17 tons ha ${ }^{-1}$ (Def $=210 \mathrm{~mm}$ ) to 14 tons $\mathrm{ha}^{-1}($ Def $=380 \mathrm{~mm})$. If soil water replacement levels are equal to or below the annual water deficit of $125 \mathrm{~mm}$, the maximum yield may reach 19 tons $\mathrm{ha}^{-1}$. If no water deficit is present, the crop's genetic potential allows it to reach yields of 22.12 tons $\mathrm{ha}^{-1}$. For plants with high-yield genetic potential, if the water deficit value of $563 \mathrm{~mm}$ is considered, yield will drop to 17 tons $\mathrm{ha}^{-1}$. If the annual water deficit is above $712 \mathrm{~mm}$, yield will be below 14 tons $\mathrm{ha}^{-1}$, a reduction by $50 \%$ due to agroclimatic limitations. The effect of water deficit varies according to the water stress level and the crop's bloom phenology (Keong and Keng, 2012), which lowers production by aborting inflorescence at a lower sexual rate than expected in years with high water supply (Corley and Tinker, 2003). In order to create monthly productivity models that describe the quantitative time relation between meteorological variables and oil palm fruit bunches, Keong and Keng (2012) reported that inflorescence abortion and sex determination are impacted by soil moisture, with a latency period of nine to 11 and 22 to 23 months prior to harvest, respectively. Those authors also point out that such evidence 


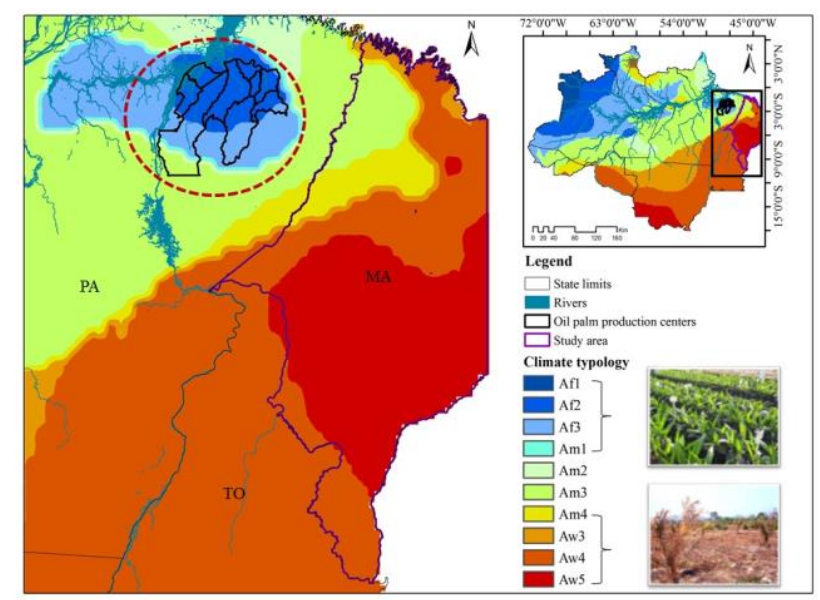

Fig 1. Climate typology in the state of Maranhão, part of the Legal Amazon, and of oil palm production centers in the state of Pará.
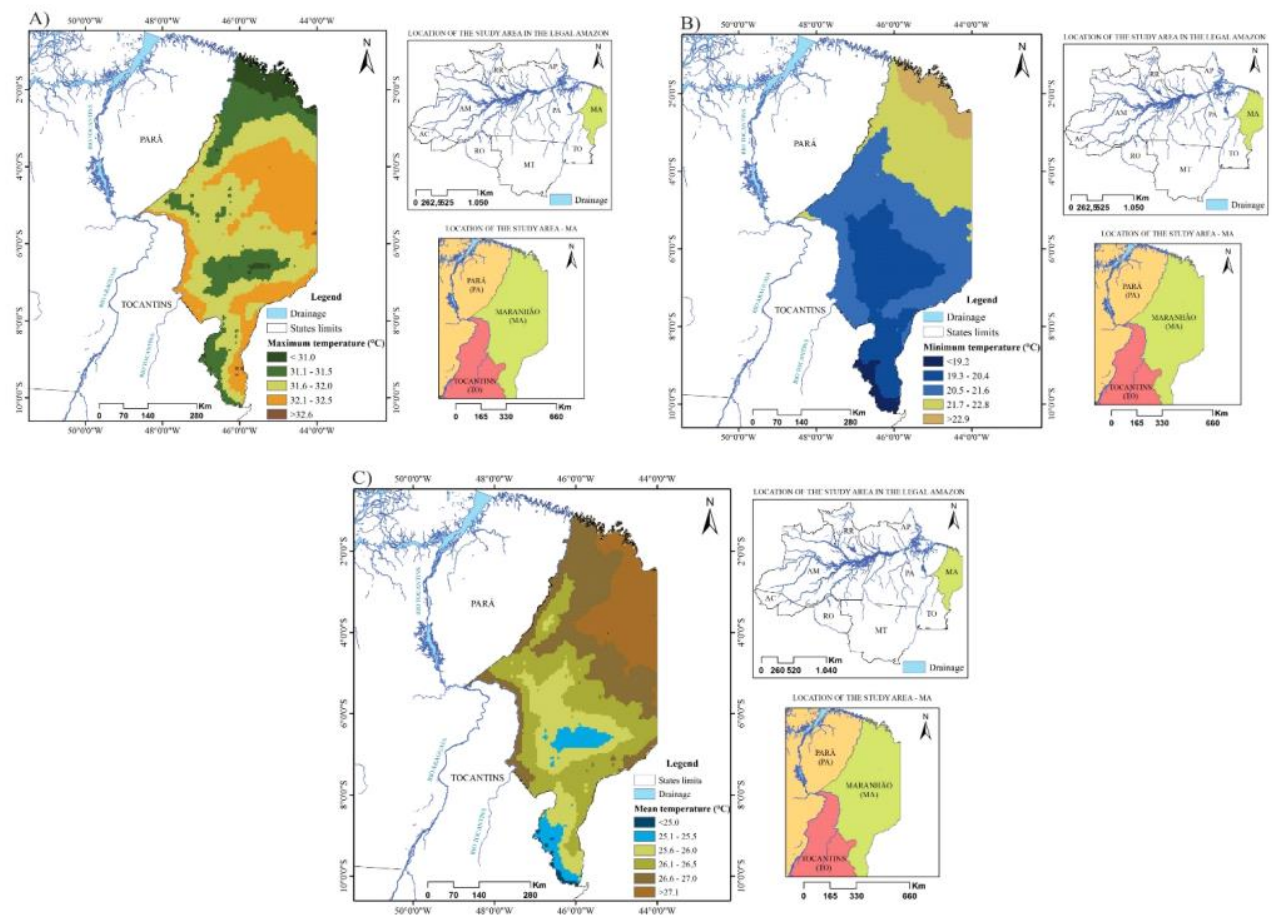

Fig 2. Maximum (A), minimum (B), and mean (C) climatologic temperature of the state of Maranhão 4 in the territory belonging to the Brazilian Amazon.

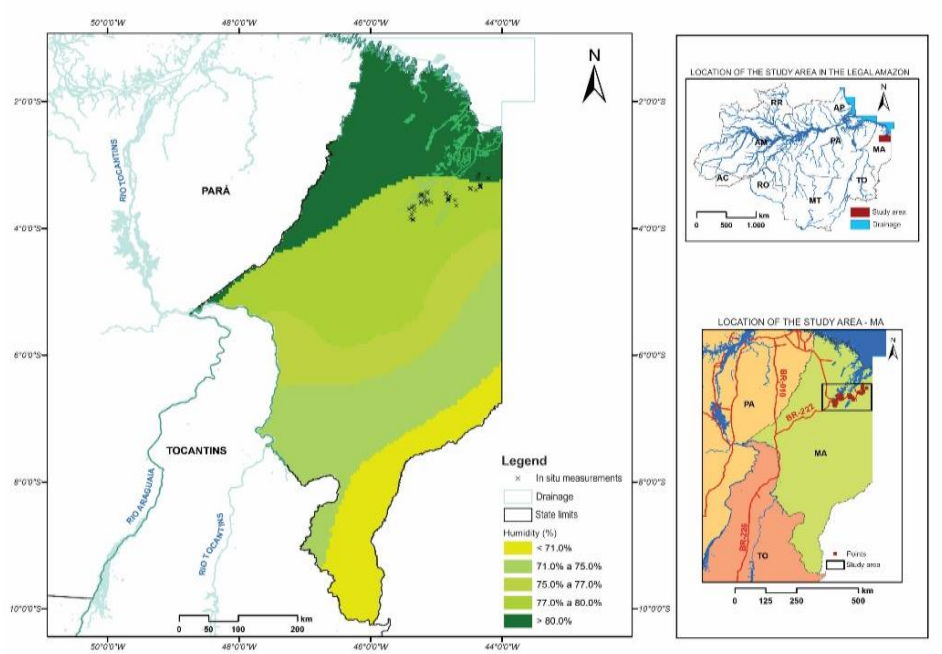

Fig 3. Climatologic relative air humidity of the state of Maranhão in its territory in the Brazilian. 


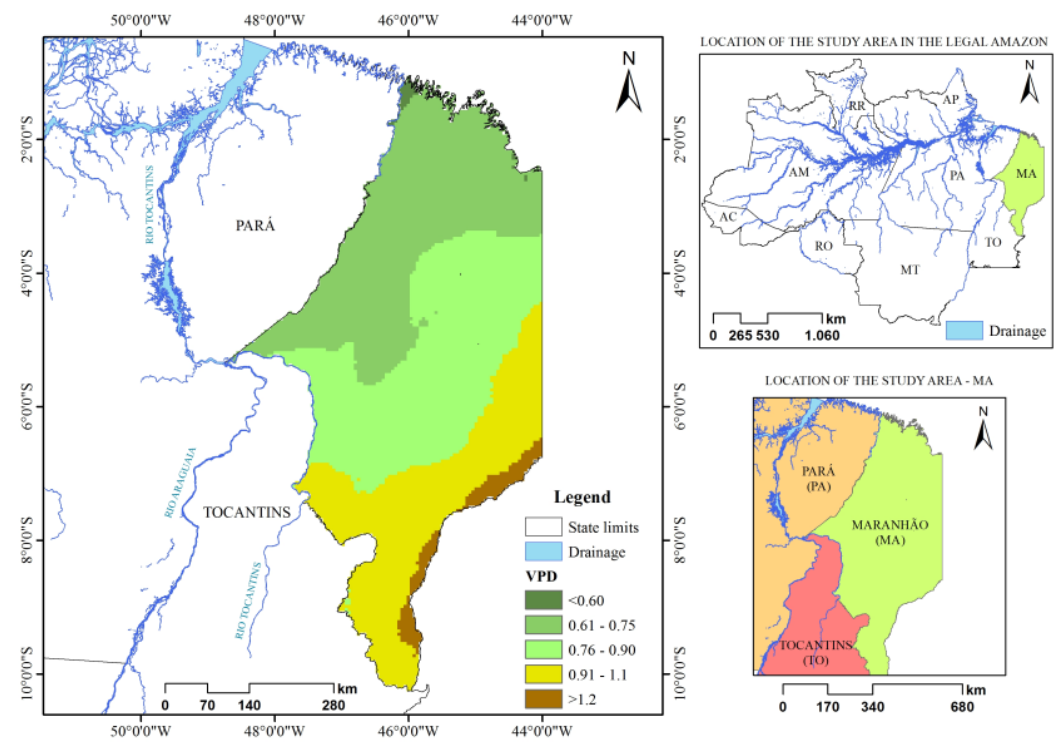

Fig 4. Climatologic vapor pressure deficit (VPD) of the state of Maranhão in its territory in the Brazilian Amazon.

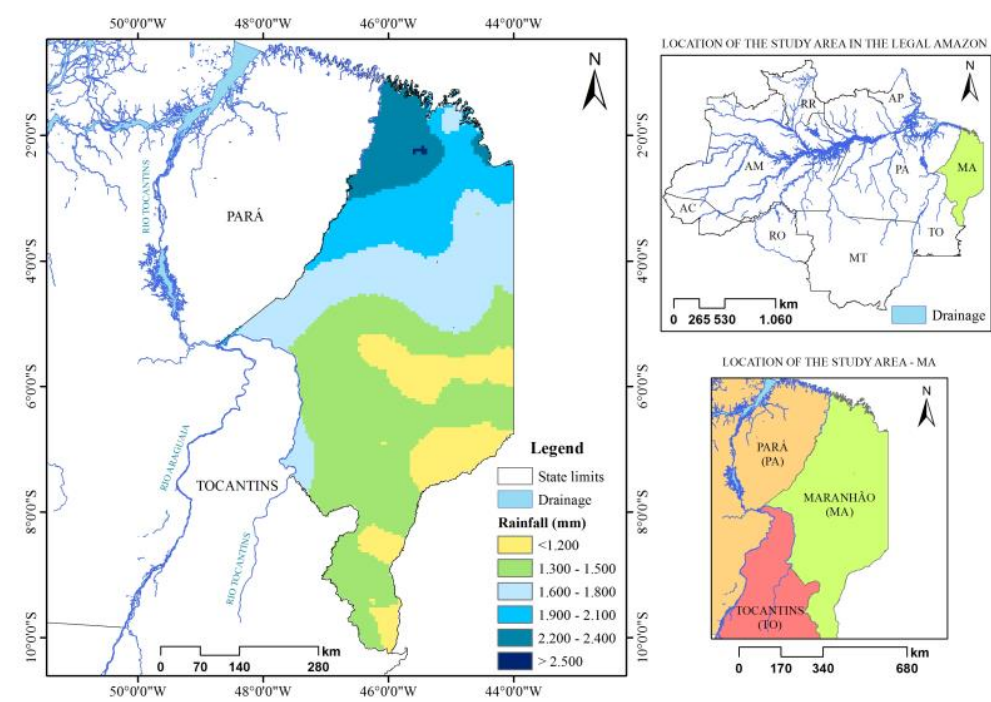

Fig 5. Climatologic annual rainfall of the state of Maranhão in its territory in the Brazilian Amazon.
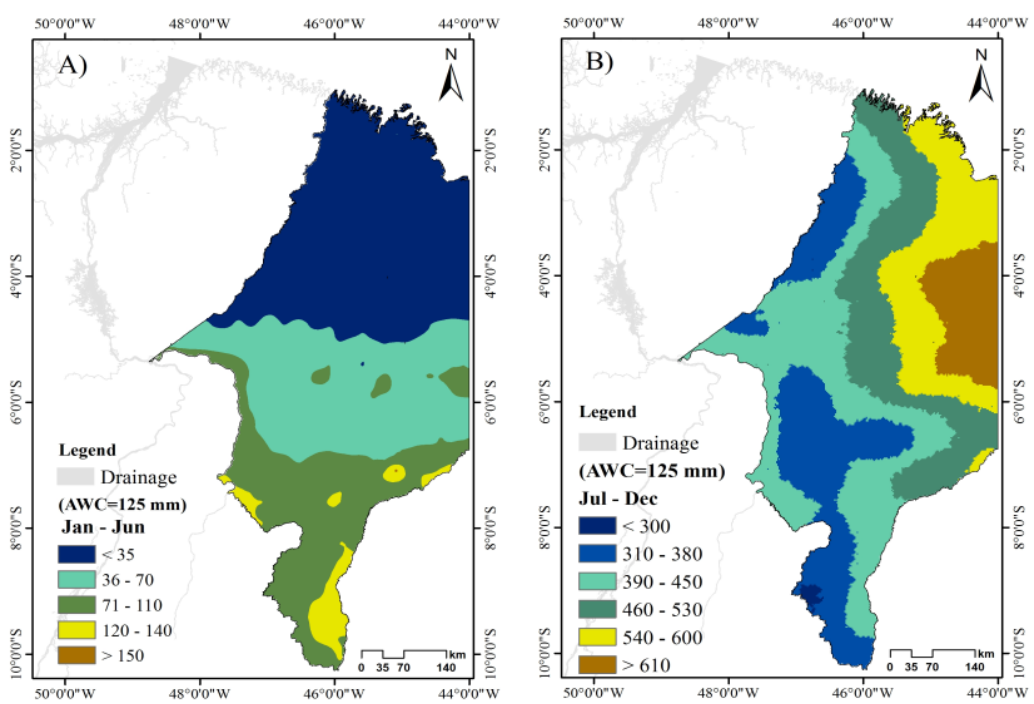

Fig 6. Total water deficit per semester - AWC $125 \mathrm{~mm}$ of the state of Maranhão in its territory in the Brazilian Amazon. 
was an indicator of yield potential, which expresses effects of interactions among productivity, time, and climate variables so that the model is able to explain $68 \%$ of the variability in crop productivity.

Studies by Mhanhmad et al. (2011) found a statistically significant correlation between mesocarp oil yield $(\mathrm{kg})$ and total rainfall, as well as the temperature accumulated over the three months prior to harvest, while seed oil yield $(\mathrm{kg})$ had a stronger correlation with accumulated temperature than with the amount of rain in observations carried out in the province of Chumphon, southern Thailand. Studies assessing oil palm plantation areas in the Peruvian Amazon using satellite imagery indicated areas with high and low yield, which were associated with the soil's water condition (Gutierrez-Velez et al., 2011). That shows those tools can help assess the species's performance.

Those authors highlighted that the high agricultural productivity reduces the pressure on forests by requiring less area to increase production, albeit while reducing biodiversity (Fitzherbert et al., 2008). Satellite images drove the assessments of the expansion of oil palm at a high-yield industrial scale in the Peruvian Amazon between 2000 and 2010 , indicating that $72 \%$ of the new plantations were in forested areas. In this context, the high agricultural yield must be accounted for in programs that incentive planting species in deforested areas in the Amazon.

It is known that, due to its extraordinary carbon retention capacity and greater $\mathrm{CO}_{2}$ flow in the soil in agroforestry systems, oil palm lays basis for the implementation of a clean development mechanism capable of improving environmental quality (Dias et al., 2010; Pezarico et al., 2013; Silva et al., 2016). However, prior to planting, it must be mainly assessed whether rainfall is enough to ensure the productivity of planted areas.

\section{Materials and Methods}

\section{Climate database}

The assessment of agroclimatic conditions used historical series of climatological data from 1961 to 1990 (INMET, 2009) and global climate databases modeled by the International Water Management Institute (IWMI), World Meteorological Organization (WMO), and International Center of Tropical Agriculture (CIAT). Those data were adjusted to each region with $95 \%$ confidence interval and standard error of 1.96 (NEW et al., 2002). The variables were interpolated for map generation, thus allowing for a spatial view of the environments assessed in the target area of this study.

\section{Water Balance Equations}

1,229 water balances were estimated based on AWC $=125$ $\mathrm{mm}$.month ${ }^{-1}$. The water balances took into account criteria both of the soil (physical and morphological attributes) and of climate (potential evapotranspiration). Evapotranspiration was obtained using the Thornthwaite and Mather (1955) equation and it was considered that the soil was completely covered with grass (Sys et al., 1978, Rolim et al., 1998). Potential evapotranspiration (ETo) was estimated using the method by Thornthwaite and Mather (1955), as described in Equations 1 and 2:

$E T o=16 \times\left(\frac{10 \times T}{I}\right)^{a} \times \frac{N}{12} \times \frac{n}{30}$
ETo $=$ Potential evapotranspiration $\left(\mathrm{mm} \cdot \mathrm{month}^{-1}\right) ;$

$\mathrm{T}=$ Mean daily temperature of the month $\left({ }^{\circ} \mathrm{C}\right)$;

$\mathrm{I}=$ Heat index;

$\mathrm{N}=$ Number of hours of sunshine (h);

$\mathrm{n}=$ Number of days in the month;

$\mathrm{a}=$ Thornthwaite parameter

$$
I=\sum_{j=1}^{12}\left(\frac{T j}{5}\right)^{1.514}
$$

$$
a=\left(6.75 \times 10^{-7} \times I^{3}\right)-\left(7.71 \times 10^{-5} \times I^{-2}\right)+\left(1.792 \times 10^{-2} \times I\right)+0.49239
$$

Based on the water deficit data, spatial analyses were performed applying the same methodological assumptions of Martorano et al. (2011) and Tourne et al. (2016) to assess the crop's responses to soil water conditions. Maximum dry matter production was estimated using the equation applied in the studies by Corley and Tinker (2003), presented in Equation 3. Reductions in those values indicate a need to meet the evapotranspiration demands.

$Y=22.12-0.0213 \times$ DEFannual

Data available on the database from IBGE (2014) were used to assess how crop expansion has been expressing its production capacity in yield. However, under climate conditions with high water supply and plants with high-yield genetic potential, Equation 4 is used.

$Y=30-0.0228 \times$ DEFanmual

\section{Conclusion}

The area in the state of Maranhão that is part of the Brazilian Amazon has soil water deficit above $125 \mathrm{~mm}$, i.e., the rainfall between July and December is below the available water capacity. The high mean air temperature leads to evapotranspiration rates that make the total annual potential evapotranspiration exceed the annual rainfall. It is concluded that planting oil palm with no crop irrigation in the Brazilian state of Maranhão, belonging to the Brazilian Amazon, is not recommended due to the high annual water deficit. The strategy to adopt irrigated crops to meet the annual atmospheric water supply may compromise the plants' water footprint. Supplying water must account for the amount of potable water used to irrigate plants and during the oil extraction process in mills and processing industries.

\section{Acknowledgements}

The authors would like to express their sincere gratitude to the federal government institutions EMBRAPA Eastern Amazon (Brazilian Agricultural Research Corporation) and FINEP (Studies and Projects Funding for financial support to UZEE Amazon Protection.

\section{References}

Brodribb TJ (2009) Xylem hydraulic physiology: the functional backbone of terrestrial plant productivity. Plant Sci. 177: 245-251

Carr MKV (2011) The Water Relations and Irrigation Requirements of Oil Palm (Elaeis Guineensis): A Review. Expl Agric. 47 (4):629-652. 
Corley RHV (2009) How much palm oil do we need? Environ Sci Policy. 12: 134-139.

Corley RHV, Tinker PB (2003) The Oil Palm, $4^{\text {th }}$ end. B.S Ltd Blackwell Publishing, Oxford, UK. 592p.

Dias ATC, Ruijven JV, Berendse F (2010) Plant species richness regulates soil respiration through changes in productivity. Oecologia. 163: 805-813.

Dufrêne E, Saugier B (1993) Gas exchange of oil palm in relation to light, vapour pressure deficit, temperature and leaf age. F. Ecol. 7: 97-104.

Fitzherbert EB, Struebig MJ, Morel A, Danielsen F, Brühl CA, Donald PF, Phalan B (2008) Howwill oil palm expansion affect biodiversity? Trends Ecology and Evolution. 23: 538-45.

Food and Agriculture Organization Of The United Nations. FAOSTAT online statistical service. 2014. Available in: <http://faostat. fao.org/>. Acesso em: 28 fev. 2015.

Gutierrez-Velez VH, DeFries R, Pinedo-Vásquez M, Uriarte M, Padoch C, Baethgen W, Fernandes K, Lim Y (2011) High-yield oil palm expansion spares land at the expense of forests in the Peruvian Amazon. Environ. Res. Lett. 6: 044029 .

Henson IE, Harun MH (2007) Short-termresponses of oil palm to an interrupted dry season in north Kedah, Malaysia. J. Oil Pal. Res. 19: 364-372.

Homma AKO, Vieira ICG (2012) Colóquio sobre dendezeiro: Prioridades de Pesquisas Econômicas, sociais e Ambientais na Amazônia. Amazônia (Banco da Amazônia) 8: 79-90.

IBGE. Instituto Brasileiro de Geografia e estatística. Produção Agrícola Municipal (2014). Available in: <http://www.sidra.ibge.gov.br/bda/agric/default.asp? $\mathrm{z}=$ tand $\mathrm{o}=11$ andi=P. <Acesso em 2 mai.2016>.

INMET - Instituto Nacional de Meteorologia. (2009) Normais Climatológicas. INMET. 465p. Available in: <http://www.inmet.gov.br/portal/>.

Kaewmai R, H-Kittikun A, Musikavong C (2012) Greenhouse gas emissions of palm oil mills in Thailand. Int. J. Greenh. Gas Control. 11: 141-151.

Keong YK, Keng WM (2012) Statistical Modeling of Weather-based Yield Forecasting for Young Mature Oil Palm. APCBEE Procedia. 4: 58-65.

Koh LP, Ghazoul J (2008) Biofuels, biodiversity, and people: understanding the conflicts and finding opportunities. Biol Conserv. 141: 2450-2460.

Lees AC, Moura NG, Almeida AS, Vieira ICG (2015) Poor Prospects for Avian Biodiversity in Amazonian Oil Palm. PLoS ONE. 10(5): e0122432.

Marenco RA, Antezana-Vera SA, Gouvêa PRS, Camargo MAB, Oliveira MF, Santos JKS (2014) Fisiologia de espécies florestais da Amazônia: fotossíntese, respiração e relações hídricas. Rev. Ceres. 61: 786-799.

Martorano LG, Monteiro DCA, Brienza Junior S, Lisboa LSS (2011) Top-bioclimate conditions associated with the natural occurrence of two Amazonian tree species for sustainable reforestation in the State of Para. In: C.A. Brebbia; E. Tiezzi; Y. Villacampa Esteve. (Org.). Ecosystems and Sustainable Development VIII. Spain: Universidad de Alicant. 144: 111-122.
Mhanhmad S, Leewanich P, Punsuvon V, Chanprame S, Srinives P (2011) Seasonal effects on bunch components and fatty acid composition in Dura oil palm (Elaeis guineensis). Afr. J. Agric. Res. 6(7): 1835-1843.

Nelson PN, Banabas M, Scotter DR, Webb MJ (2006) Using soil water depletion to measure spatial distribution of root activity in oil palm (Elaeis guineensis Jacq.) plantations. Plant Soil. 286:109-121.

New M, Lister D, Hulme M, Makin I (2002). A highresolution data set of surface climate over global land areas. Clim. Res. 21: 1-25.

Nogueira LAH (2011) Does biodiesel make sense? Energy. 36: 3659-3666.

Nkodo F, Pentane NR, Tabi FO (2016) Most responsive periods to climatic factor variations before harvest in oil palm (Elaeis guineensis Jacq.) and their quantitative relationships with yields in the coastal zone of Cameroon. Agric. Biol. J. N. Am. 7(2): 70-85.

Nouy B, Baudouin L, Dejégul N, Omoré A (1999) Le palmier à huile en conditions hydriques limitantes. Agric. Res. Development. 6: 31-45.

Pezarico CR, Vitorino ACT, Mercante FM, Daniel O (2013) Indicadores de qualidade do solo em sistemas agroflorestais. Rev. Cie. Agrárias. 56: 40-47.

Ramalho Filho A, Mota PEF (2010) Zoneamento Agroecológico do dendezeiro para as áreas desmatadas da Amazônia Brazilian. Rio de Janeiro, Embrapa Solos.44 p.

Rolim, GS, Sentelhas, PC, Barbieri, V (1998) Planilhas no ambiente EXCEL para os cálculos de balanços hídricos: normal, sequencial, de cultura e de produtividade real e potencial. Rev. Bra. Agrometeorologia, 6: 133-137.

Sheil D, Casson A, Meijaard E, Noordwijk MV, Gaskell J, Sunderland-Groves J, Wertz K, Kanninen M (2009) The impacts and opportunities of oil palm in Southeast Asia: what do we know and what do we need to know? Bogor: CIFOR. 80p.

Silva CM, Vasconcelos SS, Mourão Júnior M, Bispo CJC, Kato OR, Silva Junior AC, Castellani DC (2016) Variação temporal do efluxo de $\mathrm{CO} 2$ do solo em sistemas agroflorestais com palma de óleo na Amazônia Oriental. Acta Amaz. 46(1): 1-12.

Suttayakul P, H-Kittikun A, Suksaroj C, Mungkalasiri J, Wisansuwannakorn R, Musikavong C (2016) Water footprints of products of oil palm plantations and palm oil mills in Thailand. Sci. Total Environ. 542: 521-529.

Teles DAA, Braga MF, Rosemar Antoniassi R, Junqueira NTV, Peixoto JR, Malaquias JV (2016) Yield Analysis of Oil Palm Cultivated Under Irrigation in the Brazilian Savanna. J Am Oil Chem Soc. 93:193-199.

Thornthwaite CW, Mather JR (1995) The water balance. Centerton, Drexel Institute of Technology-Laboratory of Climatology. Clim. 8: 104 p.

Tourne DCM, Martorano LG, Brienza Junior S, Dias CTS, Lisboa LSS, Sartorio SD, Vettorazzi, CA (2016) Potential topoclimatic zones as support for forest plantation in the Amazon: Advances and challenges to growing Paricá (Schizolobium amazonicum). Env. Dev. 18: 26-35.

Villela AA, Jaccoud D'AB, Rosa LP, Freitas MV (2014) Status and prospects of oil palm in the Brazilian Amazon. Biomass Bioenerg. 67:270-278. 